\title{
Synthesis and Molecular Docking Studies of N'-benzoylsalicylhydrazide Derivatives as Antituberculosis through InhA Enzyme Inhibition
}

\author{
Harry Santosa ${ }^{1 *}$, Galih Satrio Putra1, Tegar Achsendo Yuniarta1, ${ }^{1}$ Tutuk Budiati
}

1Faculty of Pharmacy, University of Surabaya, Jalan Raya Kali Rungkut Surabaya, 60293, Indonesia

2Faculty of Pharmacy, Universitas Airlangga, Jalan Dharmawangsa Dalam Surabaya, 60286, Indonesia

Submitted: 03-10-2018

Revised: 23-11-2018

Accepted: $17-12-2018$

*Corresponding author Harry Santosa

Email:

harry_s@staff.ubya.ac.id

\begin{abstract}
The specific aims of this study is to synthesize and to study the possible mechanism of $\mathrm{N}^{\prime}$-benzoylsalicylhydrazide derivatives as an antituberculosis agent through InhA (Enoyl acyl carrier protein reductase) inhibition using in silico method. Five analogues of N'-benzoylsalicylhydrazide were synthesized using microwave irradiation from methyl salicylate as starting material, which yielded $80-90 \%$ product on average. This indicates a considerable improvement in terms of effectivity and efficiency, compared to the more conventional method using reflux condition. Characterization of the compounds were subsequently carried out by UV, FTIR, ${ }^{1} \mathrm{H}-\mathrm{NMR},{ }^{13} \mathrm{C}-\mathrm{NMR}$ spectroscopy, which confirmed that the compounds had been successfully synthesized. Ultimately, molecular docking was performed using Molegro Virtual Docker (MVD) on the active site of InhA enzyme to predict the activity of the compounds. The results showed that all compounds performed comparatively well against N-(4-Methylbenzoyl)-4benzylpiperidine as the native ligand and also yielded lower docking score than isoniazide (INH). From this study it can be concluded that $\mathrm{N}^{\prime}$-benzoylsalicylhydrazide derivatives could be synthesized using microwave irradiation with good product yield and all of the synthesized analogues are suggested to possess antituberculosis activity via InhA enzyme inhibition. In vitro activity will have to be determined in the future to validate whether $\mathrm{N}^{\prime}$-benzoylsalicylhydrazide derivatives perform well as a potential antituberculosis agent.
\end{abstract}

Key words: Antituberculosis, Benzoylsalicylhydrazide, Methyl Salicylate, InhA, Microwave synthesis, Molecular docking

\section{INTRODUCTION}

Lower respiratory tract infections were one of the top 10 deadliest diseases in 20102015. Several types of these diseases such as pneumonia, bronchitis, tuberculosis were ranked among the top 10 deadliest diseases in the world. According to WHO data, lower respiratory tract infections account for around $5.7 \%$ of deaths in the world or around 3.2 million people died in 2015 (Pietrangelo and Holland, 2018). One of the lower respiratory tract infections that has become a concern for medicals and researchers is tuberculosis infection. Tuberculosis infection accounts for half of the total mortality from lower respiratory tract infections. Therefore, this disease still ranks 9th out of the list of the top 10 deadliest diseases in the world. Based on data from the WHO in 2015 around 1.3 million $(2.4 \%)$ people died from this infection (Pietrangelo and Holland, 2018). Indonesia, as one of the most populated developing country in the world, is still facing this challenge. Based on the recent data in 2007-2013, the lower respiratory tract infections occurred frequently, with no significant change in the number of prevalence observed during this period (Indonesian Ministry of Health, 2103).

Mycobacterium tuberculosis had been found to be resistant to tuberculosis treatment with rifampin and isoniazid (INH) which is often referred to as multi-drugs resistance (MDR). Many cases of MDR has occurred during the treatment using rifampin and isoniazid as the main therapy (Dipiro et al., 2008). Rifampin possesses bactericidal 
mechanism against Mycobacterium tuberculosis as it binds strongly to the $\beta$-subunit of bacterial DNA-dependent RNA polymerase and thereby inhibits RNA synthesis (Katzung et al., 2009). Resistance against rifampin can be caused by one of the several possible point mutations in $\mathrm{rpoB}$, the gene for the $\beta$-subunit of RNA polymerase. These mutations prevent binding of rifampin to RNA polymerase (Katzung et al., 2009). As for Isoniazid (INH), its mechanism as antituberculosis against Mycobacterium tuberculosis is via inhibition of mycolic acids synthesis, which plays an important role as major components of mycobacterial cell walls. Isoniazid is a prodrug that is activated by $\mathrm{KatG}$, the mycobacterial catalase-peroxidase. The activated form of isoniazid exerts its lethal effect by forming a covalent complex with an acyl carrier protein (AcpM) and KasA, a $\beta$ ketoacyl carrier protein synthetase, which blocks mycolic acid synthesis (Katzung et al., 2009). Resistance to isoniazid has been associated with mutations resulting in overexpression of InhA, which encodes an NADH-dependent acyl carrier protein reductase; mutation or deletion of $\mathrm{KatG}$, promote mutations resulting in overexpression of ahpC. The existence of mutations in KatG expresses high levels of resistance in isoniazid (Katzung et al., 2009).

To overcome MDR problems, it is necessary to develop new drugs to reduce the high cases of MDR in tuberculosis infections. Isoniazid has a simpler chemical structure compared to rifampin, therefore it is easier to develop this compound to overcome resistance in isoniazid. Some of hydrazide derivatives were reported to have antibacterial (Maheswari et al., 2015; Kumar et al., 2014; Thomas et al., 2014) and antituberculosis activity (Maheswari et al., 2015; Lourenço et al., 2011). In this study, we synthesize five compounds of N'benzoylsalicylhydrazide derivatives (Figure 1). Based on retrosynthetic analysis (Figure 2), we proposed to synthesize N'benzoylsalicylhydrazide derivatives from methyl salicylate, hydrazine hydrate and benzoyl chloride as starting materials. Methyl salicylate would be reacted with hydrazine hydrate to produce an acylhydrazide compound, which subsequently reacted with benzoyl chloride to yield the final products. Previous study in hydrazide derivative synthesis indicates stirring method at room temperature for $30 \mathrm{~min}$, while some others suggest the application of microwave irradiation (450-900watts) for 30180s (Widiyana et al., 2017). In this study, we applied microwave irradiation on the first stage of the reaction to obtain the optimal of time and product yield.
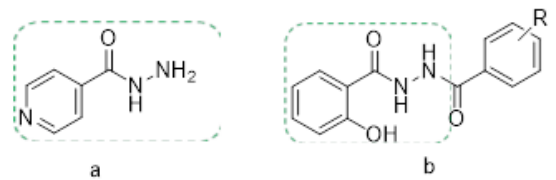

Figure 1. Isoniazid (a) and N'-benzoylsalicylhydrazide derivatives (b) chemical structure.

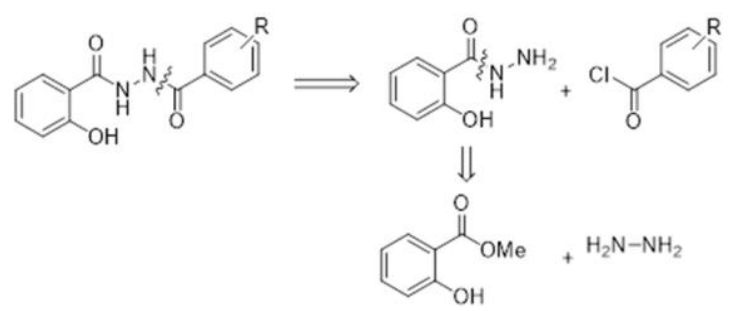

Figure 2. Retrosynthetic analysis of N'benzoylsalicylhydrazide derivatives

\section{MATERIAL AND METHODS}

All reagents such as methyl salicylate, hydrazine, some of benzoyl chloride derivatives and all solvent such as THF were purchased from standard commercial suppliers. Reactions were monitored with TLC using pre-coated aluminum sheets with GF254 silica gel, $0.2 \mathrm{~mm}$ layer thickness (E.Merck). Mobile phase used for TLC were chloroform: ethyl acetate (3:1) and the spots were visualized in UV chamber under UV light $254 \mathrm{~nm}$. Melting points of the synthesized compounds were measured with an Sybron Thermolyne MP 12615 melting point apparatus. UV spectra were obtained using Shimadzu UV1800 spectrophotometer. IR spectra were obtained using a Perkin Elmer Spectrum spectrophotometer using $\mathrm{KBr}$ disks. ${ }^{1} \mathrm{H}-\mathrm{NMR}$ and ${ }^{13} \mathrm{C}-\mathrm{NMR}$ spectra were obtained on JEOL JNM-ECS400 ( ${ }^{1} \mathrm{H}-\mathrm{NMR}: 400 \mathrm{MHz},{ }^{13} \mathrm{C}-\mathrm{NMR}$ : $100 \mathrm{MHz}$ ). Deuterated DMSO was used as solvent for these analysis. 


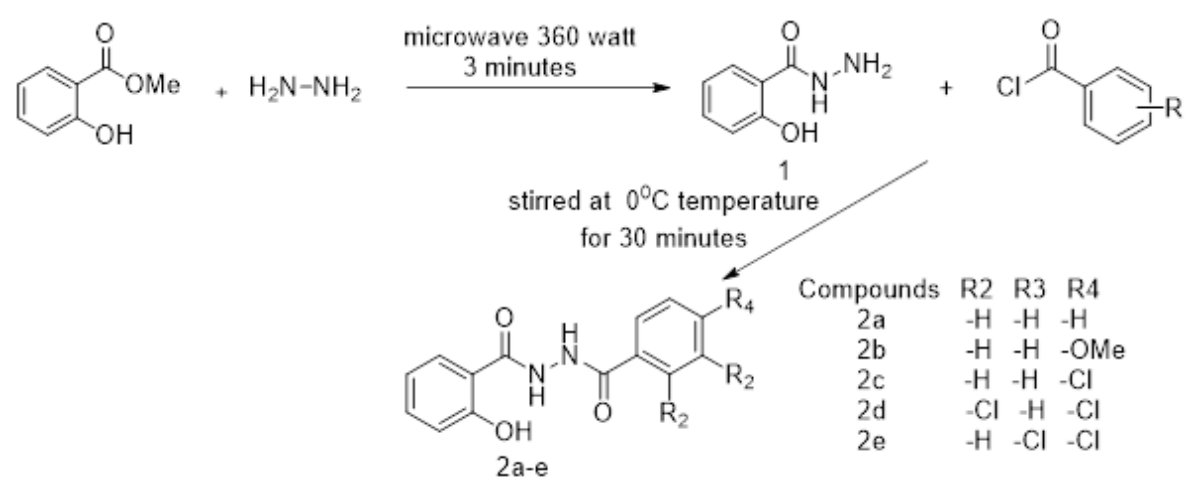

Figure 3. Synthesis of N'-benzoylsalicylhydrazide derivatives

\section{General synthesis}

Synthesis process to obtained N'benzoylsalicylhydrazide derivatives on this study (Figure 3). The first stage of reaction, methyl salicylate was reacted with hydrazine hydrate to obtanined Salicylbenzohydrazide. The second stage of reaction, Salicylbenzohydrazide was reacted with some of benzoyl chloride derivatives to obtained N'benzoylsalicylhydrazide derivatives. The detail of condition of reaction is explain in the subsequent part.

\section{Synthesis of Compound (Salicylbenzohydrazide)}

Methyl salicylate $(10 \mathrm{mmol})$ was reacted with hydrazine hydrate $(80 \%, 20 \mathrm{mmol})$ and homogenized with magnetic stirrer. The mixture was heated in microwave irradiation at $360 \mathrm{~W}$ for $3 \mathrm{~min}$ until a solid mass was formed. The mixture was then cooled and distilled water $(10 \mathrm{~mL})$ was added to the mixture. The separated solid was collected by filtration. The solid mass was crystallized by ethanol $96 \%$ to obtain Compound 1.

\section{Synthesis of Compounds 2a-e (N'- benzoylsalicylhydrazide derivatives)}

Compound $1(8.5 \mathrm{mmol})$ was added with $10 \mathrm{~mL}$ of THF as solvent and homogenized with magnetic stirrer. The mixture was then added by benzoyl chloride derivatives $(9 \mathrm{mmol})$ dropwise with constant stirring at $0^{\circ} \mathrm{C}$ for $30 \mathrm{~min}$, before the addition of $10 \%$ sodium bicarbonate solution. The latter was performed until the effervescence process ceased. The separated solid was allowed to settle down before filtered off. Ultimately, the solid was crystallized by ethanol $96 \%$ to obtained compound 2a-e.

\section{Molecular docking study}

This study was performed in notebook equipped with processor AMD A9-9420 Radeon R5, RAM 4.00 GB and 64 bit operating system. Molegro Virtual Docker (MVD) ver 5.5 (CLC Bio) was utilized for molecular docking and CS ChemBioDraw Ultra ver 11.0 (Cambridge Soft) was used to prepare our compounds (2a-e) prior to docking process. The structure of InhA protein (PDB ID: 2NSD) was obtained from the Protein Data Bank (www.rcsb.org) (Xin et al., 2007). Compounds 2a-e structures were built with ChemBioDraw Ultra 11.0 and their geometry optimization were performed using MMFF94 (Halgren, 1996). The validation of docking was carried out by redocking the native ligand of the enzyme (N-(4-Methylbenzoyl)-4benzylpiperidine) into its active site. Criteria of acceptance is set with the value of Root Mean Square Deviation (RMSD) below $2.0 \AA$ (Figure 4). After redocking process, the compounds $2 \mathrm{a}$ e were docked into active site of InhA enzyme. The binding affinity between ligand and enzyme (docking score) was evaluated using Rerank Score, and we also compared the score of the native ligand with our compounds. Rerank Score is one of the evaluation method of docking pose which is based on MolDock Score with some adjustments in the weight of each terms of the score. In addition, sp2-sp2 torsion and Lenard-Jones 12-6 potential were also introduced to further improve the accuracy 


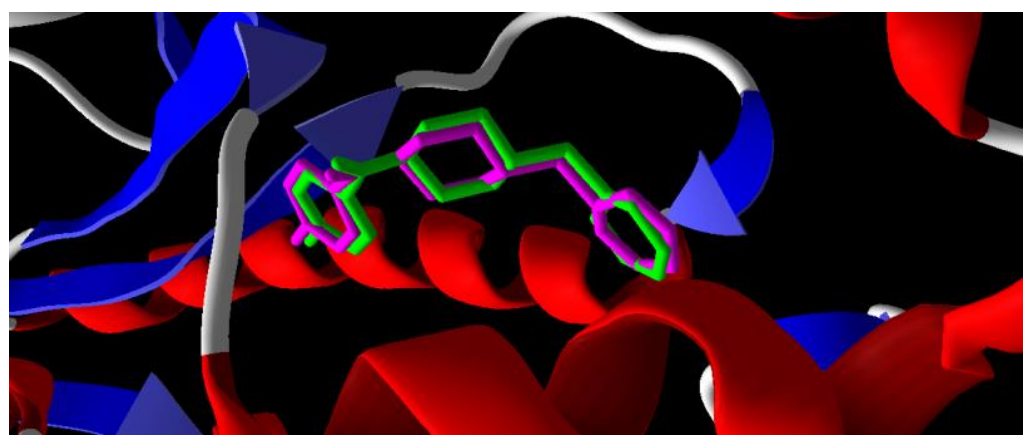

Figure 4. Comparison of its native ligand (green) with the doking result simulation (purple) by Molegro Virtual Docker (MVD) software Ver.5.5. The RMSD is $0.45 \AA$

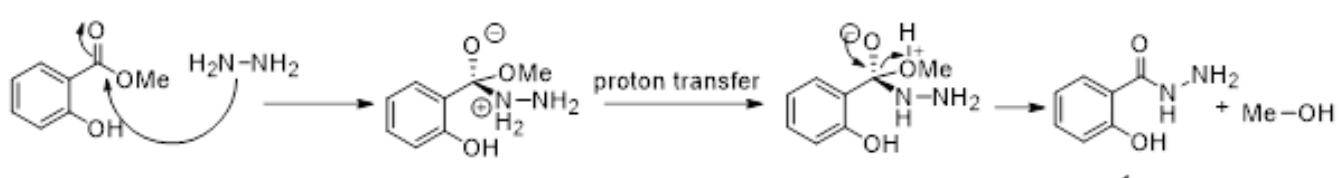

Figure 5. The mechanism reaction of the addition of nucleophilic hydrazine (-NH2) to the electrophilic carbonyl group of the ester group

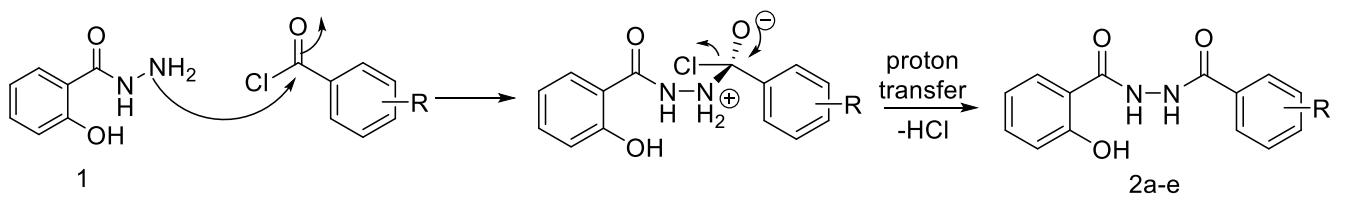

Figure 6. The mechanism reaction of the addition of nucleophilic (-NH2) compound (1) to the electrophilic carbonyl group of the acyl carbonyl groups

of docking score (Thomsen and Christensen, 2006). Low score means smaller amount of energy required in forming drug-receptor interaction which leads to an assumption that the compound is more suitable to occupying active site of the receptor.

\section{RESULT AND DISCUSSION}

The reaction of methyl salicylate with hydrazine was performed by applying microwave irradiation at $360 \mathrm{~W}$ for $3 \mathrm{~min}$. This procedure yielded (1) via nucleophilic addition of hydrazine (-NH2) to the electrophilic carbonyl group of the ester group (methyl salicylate) (Figure 5). The reaction of compound (1) with some of benzoyl chloride derivatives (4-methoxy benzoyl chloride; 4-chloro benzoyl chloride; 2,4-dichloro benzoyl chloride; 3,4dichloro benzoyl chloride) under water-free condition has successfully yielded several benzohydrazide derivatives (compounds 2a-e).
The mechanism of this reaction is the addition of nucleophilic (-NH2) compound (1) to the electrophilic carbonyl group of the acyl carbonyl groups though SNacyl mechanism (Figure 6).

\section{Compound 1 (Salicylbenzohydrazide)}

Obtained in white powders (85\%), mp : UV $\lambda \max (\mathrm{nm}): 233$; FTIR $(\mathrm{KBr}) \mathrm{cm}^{-1}: 3320$ ($\mathrm{OH}) ; 3270$ (-NH); 3055 (C-H sp2); 1647 (C=O); 1586 and 1485 (C=C aromatic); 1351 (C-N). ${ }^{1} \mathrm{H}-\mathrm{NMR}$ (400 MHz, DMSO-d6, $\left.\delta, \mathrm{ppm}\right): \delta$ $12.48(1 \mathrm{H}, \mathrm{s}) ; \delta 10.07$ (2 H, s); $\delta 7.80(1 \mathrm{H}, \mathrm{d}, 9$, $1 \mathrm{~Hz}) ; \delta 7.37(1 \mathrm{H}, \mathrm{t}, 8.8 \mathrm{~Hz}) ; \delta 6.89(1 \mathrm{H}, \mathrm{d}$, $8.5 \mathrm{~Hz}) ; \delta 6.85$ (1H; t, $8.1 \mathrm{~Hz}) ; \delta 4.66(1 \mathrm{H}, \mathrm{s})$.

\section{Compound 2a (N'-benzoyl-2-hydroxy- benzohydrazide)}

Obtained in white crystals (85\%), mp : 239-240 ${ }^{\circ} \mathrm{C}$, UV $\lambda \max (\mathrm{nm}): 302$; FTIR (KBr) $\mathrm{cm}^{-1}$ : $3302(-\mathrm{OH}) ; 3270(-\mathrm{NH}) ; 1655(\mathrm{C}=\mathrm{O})$; 1586 and 1485 (C=C aromatic); 1387(C-N). 
Table I. Molecular docking result on InhA protein

\begin{tabular}{|c|c|c|c|c|c|c|}
\hline Compound & $\begin{array}{c}\text { Rerank score } \\
\text { (kcal/mol) }\end{array}$ & $\begin{array}{c}\text { Docked } \\
\text { Pose }\end{array}$ & $\begin{array}{c}\text { Hydrogen } \\
\text { bond }\end{array}$ & $\begin{array}{c}\text { Residues } \\
\text { involved }\end{array}$ & $\begin{array}{c}\text { Steric } \\
\text { interaction }\end{array}$ & $\begin{array}{c}\text { Residues } \\
\text { involved }\end{array}$ \\
\hline & -97.86 & $\sqrt{ }$ & 1 & Ile 194 & 2 & $\begin{array}{l}\text { Ala } 157 \\
\text { Ile } 202\end{array}$ \\
\hline 11 & -29.67 & $\sqrt{ }$ & 2 & $\begin{array}{l}\text { Ile } 194 \\
\text { Thr } 196\end{array}$ & 3 & $\begin{array}{l}\text { Asp } 148 \\
\text { Ala } 191 \\
\text { Met } 99\end{array}$ \\
\hline (2a) & -88.52 & $\sqrt{ }$ & 1 & Ile 194 & - & - \\
\hline$(2 \mathrm{~b})$ & -94.56 & $\sqrt{ }$ & - & - & 4 & $\begin{array}{l}\text { Phe } 149 \\
\text { Tyr } 158 \\
\text { Pro } 193 \\
\text { Glu } 219\end{array}$ \\
\hline$(2 c)$ & -80.84 & $\sqrt{ }$ & 1 & Ile 194 & 1 & Ala 157 \\
\hline$(2 \mathrm{~d})$ & -92.82 & $\sqrt{ }$ & - & - & 3 & $\begin{array}{l}\text { Met } 155 \\
\text { Met } 199 \\
\text { Glu } 219\end{array}$ \\
\hline$(2 \mathrm{e})$ & -89.21 & $\sqrt{ }$ & 1 & Ile 194 & 1 & Leu 218 \\
\hline
\end{tabular}

${ }^{1} \mathrm{H}-\mathrm{NMR}(400 \mathrm{MHz}, \mathrm{DMSO}-\mathrm{d} 6, \delta, \mathrm{ppm}): \delta$ $11.91(1 \mathrm{H}, \mathrm{s}) ; \delta 10.65(2 \mathrm{H}, \mathrm{s}) ; \delta 7.89(3 \mathrm{H}, \mathrm{d}, 10$ $\mathrm{Hz}) ; \delta 7.58(1 \mathrm{H}, \mathrm{t}, 9.2 \mathrm{~Hz}) ; \delta 7.51-7.41(3 \mathrm{H}$, $\mathrm{m}) ; \delta$ 6.95- $6.90(2 \mathrm{H}, \mathrm{m}) ;{ }^{13} \mathrm{C}-\mathrm{NMR}(100 \mathrm{MHz}$, DMSO-d6, $\delta, \mathrm{ppm}): \delta 168.3 ; \delta 1661.1 ; 159,8 ; \delta$ 134,$7 ; \delta 132.8 ; \delta 129.1$ (2C); $\delta 128.8 ; \delta 128.0$ (2C); $\delta$ 119.6; $\delta$ 117.9; $\delta$ 115.0. All these spectral data are in agreement with the structure of compound N'-benzoyl-2hydroxybenzohydrazide

\section{Compound 2b (2-hydroxy-N'-(4- methoxybenzoyl)benzohydrazide)}

Obtained in white powders $(82 \%), \mathrm{mp}$ : $215-216^{\circ} \mathrm{C}$; UV $\lambda \max (\mathrm{nm}): 301$; FTIR (KBr) $\mathrm{cm}^{-1}$ : $3309(-\mathrm{OH}) ; 3270(-\mathrm{NH}) ; 3054(\mathrm{C}-\mathrm{H}$ sp2); 1606 (C=O); 1586 and $1483(\mathrm{C}=\mathrm{C}$ aromatic); 1284 (C-O); $1264(\mathrm{C}-\mathrm{N}) ; 1174$ (-CH sp3); ${ }^{1} \mathrm{H}-\mathrm{NMR}$ (400 MHz, DMSO-d6, $\delta$, ppm) : $\delta 11.93(1 \mathrm{H}, \mathrm{s}) ; \delta 10,60(1 \mathrm{H}, \mathrm{s}) ; \delta 10,49(1 \mathrm{H}$, $\mathrm{s}) ; 7,90-7,86(3 \mathrm{H}, \mathrm{m}) ; \delta$ 7.44-7.40 (1 H, m); $\delta$ 7.15 (1 H, d, 11,5 Hz); 6.94-6.92 (2H, m); $\delta$ $3.79(3 \mathrm{H}, \mathrm{s}) ;{ }^{13} \mathrm{C}-\mathrm{NMR}(100 \mathrm{MHz}, \mathrm{DMSO}-\mathrm{d} 6$, $\delta, \mathrm{ppm}): \delta 168.4 ; \delta 155.6 ; \delta 162.6 ; \delta$ 134.7; $\delta$ 129.9 (2C); $\delta 128.7 ; \delta 124.9 ; \delta 119.6 ; \delta 117.9 ; \delta$ 115.0; $\delta 114.3 \quad(2 \mathrm{C}) ; \delta$ 55.9. All these spectral data are in agreement with the structure of compound 2-hydroxy-N'-(4methoxybenzoyl)-benzohydrazide.

\section{Compound 2c (N'-(4-chlorobenzoyl)-2-} hydroxybenzohydrazide)

Obtained in white crystals $(92 \%), \mathrm{mp}$ : 233-234 ${ }^{\circ} \mathrm{C}$, UV $\lambda \max (\mathrm{nm})$ : 302; FTIR (KBr) 
$\mathrm{cm}^{-1}$ : 3259 (-OH); $3270(-\mathrm{NH}) ; 1607$ (C=O); 1565 and 1475 ( $\mathrm{C}=\mathrm{C}$ aromatic); $1175(\mathrm{C}-\mathrm{N})$; 737 (C-Cl); ${ }^{1} \mathrm{H}-\mathrm{NMR}$ (400MHz, DMSO-d6, $\delta$, ppm) : $\delta 11.85$ (1H, s); $\delta 10.90(1 \mathrm{H}, \mathrm{s}) ; \delta 10.75$ $(1 \mathrm{H}, \mathrm{s}) ; \delta 7.89(3 \mathrm{H}, \mathrm{t}, 10,2 \mathrm{~Hz}) ; \delta 7.58(2 \mathrm{H}, \mathrm{d}$, $11.0 \mathrm{~Hz}) ; \delta 7.42(1 \mathrm{H}, \mathrm{t}, 8.7 \mathrm{~Hz}) ; \delta$ 6.95-6.92 $(2 \mathrm{H}, \mathrm{m}) ;{ }^{13} \mathrm{C}-\mathrm{NMR}(100 \mathrm{MHz}, \mathrm{DMSO}-\mathrm{d} 6, \delta$, ppm) $: \delta 168.1 ; \delta 165.1 ; \delta 159.7 ; \delta 137.4 ; \delta$ $134.7 ; \delta 131.5 ; \delta 129.9(2 \mathrm{C}) ; \delta 129.2$ (2C); $\delta$ $128.9 ; \delta$ 119.6; $\delta$ 117.9; $\delta$ 115.1. All these spectral data are in agreement with the structure of compound N'-(4-chlorobenzoyl)-2hydroxy-benzohydrazide.

\section{Compound 2d (2,4-dichloro-N'-(2- hydroxybenzoyl)benzohydrazide)}

Obtained in white crystals (81\%), mp : 236-238 ${ }^{\circ} \mathrm{C}$, UV $\lambda \max (\mathrm{nm}): 294$; FTIR $(\mathrm{KBr})$ $\mathrm{cm}^{-1}$ : $3321(-\mathrm{OH}) ; 3290(-\mathrm{NH}) ; 3065$ (C-H sp2); 1635 (C=O); 1607 and $1475 \quad(\mathrm{C}=\mathrm{C}$ aromatic); 1375 (C-N); 571 (C-Cl); ${ }^{1} \mathrm{H}-\mathrm{NMR}$ (400MHz, DMSO-d6, $\delta, \mathrm{ppm}): \delta 11.87(1 \mathrm{H}, \mathrm{s})$; $\delta 10.75(1 \mathrm{H}, \mathrm{s}) ; \delta 10.71(1 \mathrm{H}, \mathrm{s}), \delta 7.85(1 \mathrm{H}, \mathrm{d}$, $10.0 \mathrm{~Hz}) ; \delta 7.73(1 \mathrm{H}, \mathrm{s}) ; \delta$ 7.55-7.41 (3 H, m); $\delta$ 6.96-6.90 (2 H. m); ${ }^{13} \mathrm{C}-\mathrm{NMR}(100 \mathrm{MHz}$, DMSO-d6, $\delta, \mathrm{ppm}): \delta$ 167.7; $\delta$ 164.9; $\delta$ 159.6; $\delta$ 135.9; $\delta 134.8 ; \delta 133.7 ; \delta$ 132.3; $\delta$ 131.3; $\delta$ $130.1 ; \delta 129.0 ; \delta 128.0 ; \delta$ 117.9; $\delta$ 115.0. All these spectral data are in agreement with the structure of compound 2,4-dichloro-N'-(2hydroxybenzoyl)benzohydrazide.

\section{Compound 2e (3,4-dichloro-N'-(2- hydroxybenzoyl)benzohydrazide)}

Obtained in white crystals (93\%), mp : 249-241 ${ }^{\circ} \mathrm{C}$, UV $\lambda \max (\mathrm{nm}): 300$; FTIR (KBr) $\mathrm{cm}^{-1}$ : $3190(-\mathrm{OH}) ; 3120(-\mathrm{NH}) ; 1606(\mathrm{C}=\mathrm{O})$; 1504 and 1470 ( $\mathrm{C}=\mathrm{C}$ aromatic); $1382(\mathrm{C}-\mathrm{N})$; 642 (C-Cl); 1H-NMR (400MHz, DMSO-d6, $\delta$, ppm) : $\delta 11.80 ; \delta 10.89 ; \delta 10.70 ; \delta 8.11(1 \mathrm{H}, \mathrm{d}$, $3.0 \mathrm{~Hz}) ; \delta$ 7.86-6.94 (6 H, m); ${ }^{13} \mathrm{C}-\mathrm{NMR}(100$ MHz, DMSO-d6, $\delta$, ppm) : $\delta 167.9 ; \delta$ 163.8; $\delta$ $159.5 ; \delta 135.4 ; 134.8 ; \delta 133.1 ; \delta 132.1 ; \delta$ 131.6; $129.9 ; \delta 129.0 ; \delta 128.3 ; \delta 119.7 ; \delta 117.9 ; \delta$ 115.2 All these spectral data are in agreement with the structure of compound 3,4-dichloroN'-(2-hydroxybenzoyl) benzohydrazide

\section{Molecular docking study}

Compounds $2 \mathrm{a}$-e were docked in to the active site of enoyl acyl carrier protein reductase (InhA) This enzyme was chosen, since it catalyzes the reduction of long-chain trans-2-enoyl-ACP in the type II fatty acid biosynthesis pathway of Mycobacterium tuberculosis. Inhibition of InhA disrupts the biosynthesis of the mycolic acids that were main component of the mycobacterial cell wall. The mechanism of action of isoniazid is via inhibition of the enzyme. However, Mycobacterium tuberculosis has been found to be resistant to isoniazid. Compounds $2 \mathrm{a}$-e are N'-benzoyl-2-hydroxybenzohydrazide erivatives that were developed are found to be similar with isoniazid. Thus, compounds $2 \mathrm{a}$-e were suggested to be potent to inhibit InhA.

Based on molecular docking result (Table I; Figure 7), it is shown that compounds 2a-e have lower docking score (-94.56 to $-80.84 \mathrm{kcal} / \mathrm{mol})$ than isoniazid $(-29.67 \mathrm{kcal} / \mathrm{mol})$ and some of the compounds possess comparable score to $\mathrm{N}$-(4-Methylbenzoyl)-4-benzyl-piperidine $(-97.86 \mathrm{kcal} / \mathrm{mol})$. Interaction between native ligand and isoniazid with InhA showed a hydrogen bond with Ile 194 residues and some steric interactions on residues such as Ala 157 and Ile 202. Compound 2a; 2c; 2e were predicted to form hydrogen bond interaction with Ile 194 and some steric interaction. Hydrogen bond on Ile 194 residue was predicted as one of the most important interaction for a ligand to inhibit InhA activity. Both N-(4-Methylbenzoyl)-4-benzylpiperidine and isoniazid interact with this residue in aforementioned manner. Based on the results of docking score and analysis of hydrogen bond and steric interactions with InhA,

compound 2a-e were suggested to have antituberculosis activity through the mechanism of inhibition of InhA enzyme. This prediction can be used as a foundation for further investigation in enzymatic and other in vitro assay.

\section{CONCLUSION}

The method to obtain N'-benzoyl-2hydroxybenzohydrazide derivatives by microwave irradiation is more time efficient with satisfactory product yield (80-90\%). Compounds $2 \mathrm{a}-\mathrm{e}$ are suggested to possess antituberculosis activity by inhibiting $\operatorname{Inh} A$ enzyme based on molecular docking that have been conducted. 


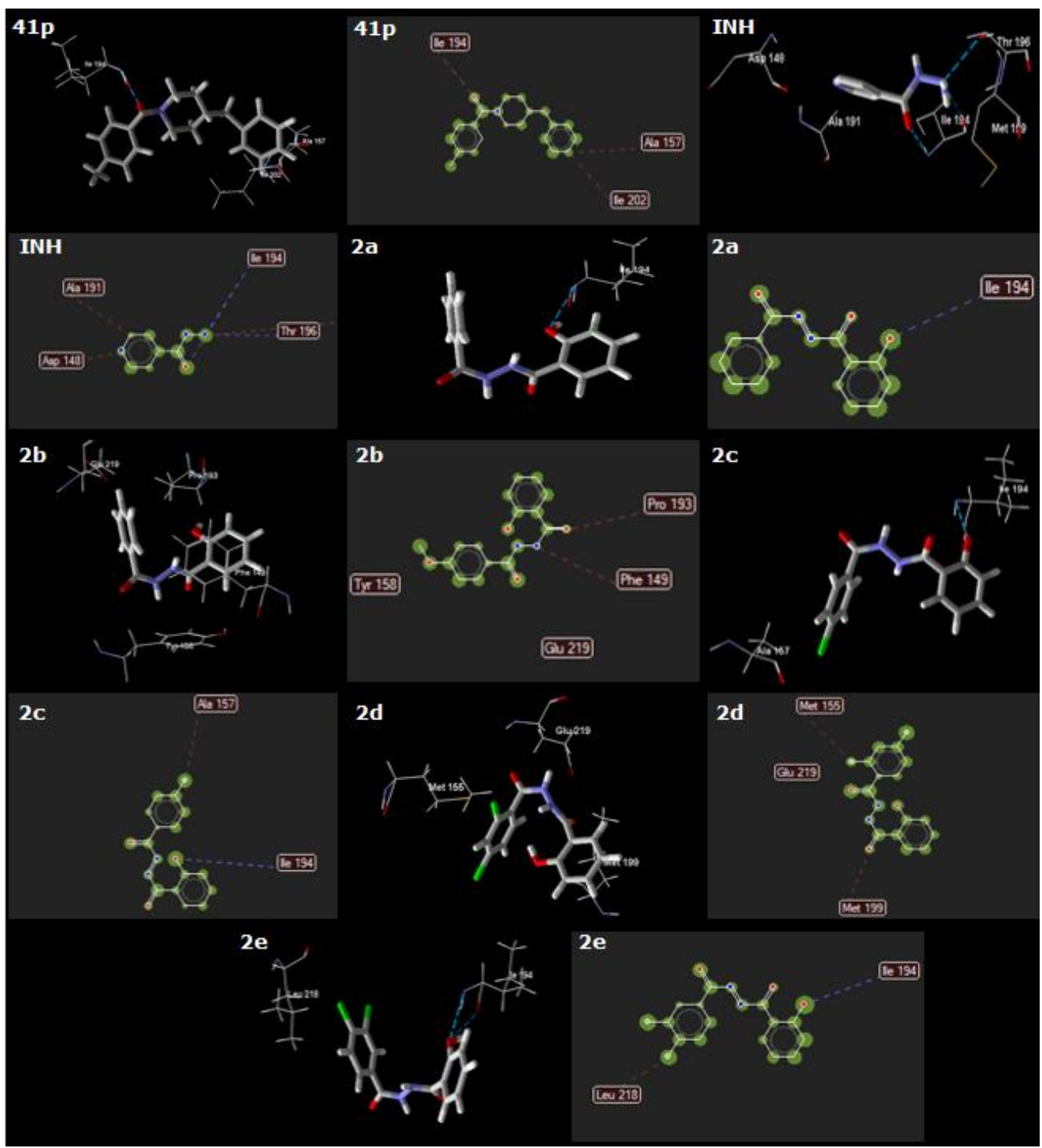

Figure 7. The Interaction betwwen native ligand (4PI), INH, and compounds 2a-e into active site InhA protein

\section{ACKNOWLEDGEMENT}

We would like to thank Professor Siswandono from Airlangga University for license of docking program (Molegro Virtual Docker software Ver.5.5.)

\section{REFERENCES}

Indonesian Ministry of Health. 2013. Riset Kesehatan Dasar.

Joseph D,. Robert L., Gary C., Gary R., Barbara G., Michael PL. 2008. Pharmacotherapy: apathophysiologic approach 7th. New
York,McGraw-Hill Medical. pp 18392096.

Katzung BG., Masters SB., Trevor AJ. 2009. Basic \& Clinical Pharmacology Edition 11th. New York: McGraw-Hill Companies. pp 1089-1093

Lourenço MCS., Souza MVN., Pinheiro A, C., Ferreira ML., Gonçalves RSB., Nogueira TC., Peralta MA. 2007. Evaluation of anti-tubercular activity of nicotinic and isoniazid analogues. ARKIVOC (xv) 181-191 
Maheswari R., Manjula J. 2015. Synthesis, Characterization and Biological Applications of Benzohydrazide derivatives. Int J of App Res. 1(10): 587592

Pietrangelo A., 2017. Holland K. The Top 10 Deadliest Diseases. Retrieved: September 5th, 2018, from https://www.healthline.com/health/top-10deadliest-diseases\#cad

Pradeep K., Narasimhan B., Ramasamy K., Mani V., Mishra RK., Majeed ABA. 2014. Synthesis, antimicrobial, anticancer evaluation and QSAR studies of 2/3-bromo-N0-(substituted benzylidene/3-phenylallylidene)benzohydrazides. Arab J of Chemistry. XXX.

Thomas AB., Nanda RK., Kothapalli LP., Deshpande AV. 2011. Synthesis and Antimicrobial Activity of N-[2(aryl/substituted aryl)-4-oxo-1,3-thiazolidin3-yl]pyridine-4-carboxamide. $J$ of the Kor Chem Soc. 55, 6, 960-968
Thomas HA. 1996. Merck Molecular Force Field. I Basis, form, scope, parametrization, and performance of MMFF94. J. Com. Chem. 17(5-6): 490-519.

Thomsen R., Christensen MH. 2006. MolDock: A New Technique for High-Accuracy Molecular Docking. J. Med. Chem. 49: 3315-3321.

Widiyana AP., Putra GS., Sulistyowaty MI., Hardjono S., Budiati T. 2017. Method Optimization of 2,3Disubtitutedquinazolin-4(3H)-One Derivatives. I of Chem and Pharm Res. 9(8):24-28

Xin H., Alian, A., Montellano, PRO. 2007. Inhibition of the Mycobacterium tuberculosis enoyl acyl carrier protein reductase InhA by arylamides. Bioorg Med Chem. 15(21): 6649-6658 